\title{
Science academies call for global goal of zero population growth
}

New Delhi. The scientists of Africa, the Republic of Ireland and the Vatican said no. Those from Japan and Argentina declared that the matter was "outside their competence". And academies from four other countries found reasons not to sign the statement on population that emerged from the firstever summit of the world's scientific academies, held in New Delhi last week.

But the scientific academies of India and China -- representing the world's two most heavily populated nations - were among 56 such institutions to endorse a 15-page statement calling for "zero population growth within the lifetime of our children", and

\section{Why Africa said no}

New Delhi. The African Academy of Sciences (AAS) refused to sign the final statement of last week's population summit of the world's scientific academies, which calls for a global reduction in fertility rates, saying that it does not consider overpopulation to be a problem in Africa.

"For Africa, population remains an important resource for development, without which the continent's natural resources will remain latent and unexploited", the academy, which was one of the 15 that sponsored the summit, said in a statement presented to the meeting.

According to J. K. Egunjobi, head of programmes at the AAS, who read out the note of dissent, the most important Issue now facing Africa is development, not population growth.

"Human resource development must therefore form part of the populationresource issue in the forthcoming Cairo conference [on population control]", he told the summit.

Egunjobi says that, for most native Africans, marriage is important both for companionship and for procreation. “The [summit] statement completely ignores the fact that for certain parts of Africa, infertility is a major problem", he said.

The AAS statement says that the international economic environment in which Africa's development programmes are defined and executed is "an important variable in the population debate". It adds: "The contribution of the North to Africa's population predicament must be acknowledged in any suggestion as to how that situation is to be confronted." K.S.J. describing this as essential for dealing successfully with humanity's social, economic and environmental problems.

The so-called New Delhi statement was drafted by the Royal Society of London, the US National Academy of Sciences, the Royal Swedish Academy of Sciences and the Indian National Science Academy (INSA). It was sent in advance to all the world's academies, asking for their endorsement.

According to Prakash Tandon, a past president of INSA and spokesman for the meeting, the Irish and pontifical academies had rejected it outright, perhaps not surprisingly given the Pope's recent renewal of his criticisms of birth control.

The academies of Spain, Georgia, Armenia and Italy offered excuses for not signing, some saying their officials had been on vacation, others that they had not had time to read the document. The most explicit disagreement came from the African Academy of Sciences - one of the sponsors of the summit - which issued a dissenting note saying that overpopulation is not a problem in Africa (see box).

The joint statement urges governments to adopt an "integrated policy on population and sustainable development". It blames both rich and poor nations for adding to environmental damage, but acknowledges that development is a "legitimate expectation of less developed countries".

The statement claims that zero population growth is achievable, given time, political will and intelligent use of science and technology. But only if "appropriate policy decisions are taken now to bring about the requisite social change".

A key message of the summit was that fertility rates cannot be reduced merely by

\section{IMAGE \\ UNAVAILABLE \\ FOR COPYRIGHT REASONS}

\section{India's population is likely to reach one} billion by the year 2000 .

providing more contraceptives. Family planning has to be seen as part of the broader "reproductive health service" that includes the elimination of sex-based inequalities, and the provision of basic requirements such as clean water and sanitation.

Some participants complained that the summit soft-pedalled on the relationship between population growth and use of resources. The final declaration calls for "a new ethic that eschews wasteful consumption". But Michael Chadwick, director of the Stockholm Environmental Institute, said he would have liked more quantification of the issues, and target-orientated goals for countries to commit themselves to.

Others criticized the document for not acknowledging the central role of women in all issues concerning population and development. But whatever its shortcomings, Zhao Qiguo, representing the Chinese academy, welcomed what he described as a "good document", adding that the question of resource use was "political and beyond the purview of scientists". K. S. Jayaraman

\section{NIH awards gene centre grants}

San Francisco. Three US universities - the University of California, San Francisco (UCSF), the University of Pennsylvania and the University of Washington in Seattle - are to receive grants from the National Institute of Diabetes and Digestive and Kidney Diseases (NIDDK) to establish centres for developing the application of gene therapy to the treatment of cystic fibrosis.

The new grants, each of $\$ 2.25$ million a year over five years, are intended to bring together basic, pre-clinical and clinical research in the field, and have been specifically recommended by Congress as part of its efforts to promote the whole field of gene therapy research.

They come on top of a separate decision by the National Heart, Lung and Blood Institute to award six universities a total of $\$ 4$ million each year for five years to support research into gene therapy for cystic fibrosis and other heart, lung and blood diseases.

Each centre being funded by the NIDDK is intended to act as a regional hub that the $\mathrm{NIH}$ hopes will strengthen gene therapy research across a variety of diseases and encourage innovative pilot studies.

In San Francisco, for example, more than 20 investigators drawn from UCSF and nearby UC, Davis, will develop transgenic animals, study the ways specialized cells function, analyse the molecular packaging of genes and improve techniques to transport genes into cells.

Sally Lehman 